\title{
ANALISIS GURU NON PENJAS PADA KINERJA GURU PENJAS DALAM SISTEM PEMBELAJARAN DARING SAAT MASA PANDEMI DI SMA N 2 DEMAK DAN SMA N 1 DEMPET
}

Indah Kusuma Wardhani ${ }^{1)}$

${ }^{1}$ FPIPSKR, Universitas PGRI Semarang

email: Indahkusumaw1306@gmail.com

\begin{tabular}{l}
\hline Artikel Info \\
\hline \\
Koresponden penulis: \\
Indah Kusuma Wardhani \\
Email: \\
Indahkusumaw1306@gmail.com
\end{tabular}

Diterima 14 Desember 2021

Direview 18 Januari 2022

Disetujui 29 Januari 2022

$\checkmark$ Dipublikasi 31 Januari 2022

Kata Kunci: Guru Penjas, Guru Non Penjas, Pembelajran, Daring

Keywords:

Physical Education Teacher, Non Physical

Education Teacher, Learning, Online

\begin{abstract}
Abstrak
Tujuan penelitian ini adalah untuk mendiskripsikan kinerja guru penjas dalam sistem pembelajaran daring saat pandemi diSMA N 2 Demak dan SMA N 1 Dempet.Jenis penelitian ini adalah penelitian deskriptif kuantitatif. pengambilan sampel dilakukan secara random sampling, populasi dalam penelitian ini adalah seluruh guru non penjas yang ada di SMAN 1 Dempet dan SMAN Instrumen berupa angket mengadopsi dari skripsi Nurochim (2009) dengan judul "Persepsi Guru NonPenjasorkes Terhadap Kinerja Guru Penjasorkes" Hasil penelitian ini di SMA N 1 Dempet Demak berada pada kategori "baik" sebesar 92,3\% (24 guru), "sedang”sebesar 7,7\% (2 guru), "rendah" sebesar $0 \%$ (0 guru) dan "sangat rendah" sebesar 0\% (0 guru) sedangkan di SMA N 2 Demak Demak berada pada kategori "baik" sebesar 100\% (26 guru), "sedang” sebesar 0\% (0 guru), "rendah” sebesar 0\% (0 guru) dan "sangat rendah" sebesar 0\% (0 guru). Berdasarkan nilai rata-rata analisa guru non penjas dalam kinerja guru penjas pada proses pembelajaran daring saat masapandemi di $\begin{array}{llll}S M A & N & 1\end{array}$ DempetDemak sebesar 92,3 \% dan SMA N 2 Demak sebesar $100 \%$ berada pada kategori baik
\end{abstract}

\begin{abstract}
The purpose of this study was to describe the performance of physical education teachers in the online learning system during a pandemic at SMA N 2 Demak and SMA N 1 Dempet. This type of research is a quantitative descriptive study. Sampling was done by random sampling, the population in this study were all non-physical and physical education teachers at SMAN 1 Dempet and SMAN. Instruments in the form of a questionnaire adopted from Nurochim's thesis (2009) with the title "Perceptions of Non-Personal Teachers" Physical Education on Physical Education Teacher Performance" The results of this study at SMA N 1 Dempet Demak were in the "good" category of 92.3\% (24 teachers), "medium" 7.7\% (2 teachers), "low" 0\% (0 teachers) and "very low" at 0\% (0 teachers) while at SMA N 2 Demak Demak were in the "good" category of 100\% (26 teachers), "moderate" at 0\% (0 teachers), "low " at 0\% (0 teachers) and "very low" at 0\% (0 teachers). Based on the average value of the analysis of non-physical education teachers in the performance of physical education teachers in the online learning process during the pandemic at SMA $N 1$ Dempet, Demak, it was $92.3 \%$ and SMA N 2 Demak was $100 \%$ in the good category
\end{abstract}


http://jurnal.unipasby.ac.id/index.php/stand/about/submissions jurnal.stand@unipasby.ac.id

\section{PENDAhUlUAN}

Pendidikan merupakan metode mencerdaskan kehidupan warga sesuaidengan alinea keempat Pembukaan Undang- Undang Dasar Negeri Republik Indonesia Tahun 1945. Perihal tersebut ialah harapanbuat tercapainya tujuan pembelajaran nasional. Pertumbuhan era dikala ini memerlukan sumber energi manusia yang bermutu guna bersaing dengan negeri maju yang lain. Pembelajaran memegang peranan yang sangat berarti dalam menghasilkan sumber energi manusia yang bermutu. Tidak hanya mengupayakan pembelajaran yang bermutu, pemerintah serta perlu membagikan pemerataan pembelajaran dasar untuk tiap masyarakat negara Indonesia supaya bisa ikut dan memajukan kehidupan bangsa (Nurwijayanto, (2013: 9)

Berolahraga merupakan pemakaian sistematis dari kegiatan raga yang direncanakan dalam kerangka sistem pembelajaran nasional Rosdiani (2013: 23), yang tujuannya merupakan buat meningkatkan serta meningkatkan orangdalam tentang organik, neuromuskular, anggapan, kognisi, serta emosi. Pembelajaran jasmani sangat berarti untuk siswa, sebab pembelajaran jasmani membagikan peluang kepada siswa buat meningkatkan kemampuannya yang belum tumbuh, tidak cuma dalam gerak raga serta mental, namun pula dalam aspek kognitif serta emosional. Bawah pembelajaran jasmani merupakan buat meningkatkan sportivitas, kejujuran serta disiplin siswa, jiwa sosial yang besar, rasa tanggung jawab, semangat kerjasama, yakin diri serta demokrasi lewat latihan jasmani, sehingga membentuk kepribadian siswa. Berkaitan dengan proses pembelajaran, diperlukan metode, strategi dan model pembelajaran yang tepat dalam proses pembelajaran jasmani. Modus pembelajaran dapat ditentukan oleh guru berdasarkan situasi dan kondisi di sekolah yang dipadukan dengan tujuan dan materi pembelajaran. Dunia saat ini sedang mengalami wabah virus corona, termasuk Indonesia, dimana pendidikan di Indonesia akan dilaksanakan melalui sistem pembelajaran online. Coronavirus atau Sindrom Pernafasan Akut Parah Coronavirus 2 (SARS-CoV-2) adalah virus yang menyerang sistem pernapasan. Penyakit ini disebabkan oleh infeksi virus bernama Covid-19 yang dapat menyebabkan gangguan pernapasan ringan, infeksi paruparu berat, bahkan kematian. Dari dampak wabah virus corona ini, semua kegiatan proses pendidikan di Indonesia dilakukan pembelajaran siswa yang diharuskan untuk belajar dirumah sesuai dengan surat edaran yang dikeluarkan pemerintah pada bulan Juni jika vaksinasi covid-19 sampai selesai.Segala kegiatan di dalam dan di luar ruangan di semua sektor sementara waktu ditunda demi mengurangi rantai penyebaran virus corona terutama pada bidang pendidikan.

Pembelajaran online dapat dijelaskan sebagai pemakaian internet dalam alat pelaksanaannya tanpa perlu adanya 
pembelajaran tatap muka antara pendidik dan perutusan didik. Bagi (Harnani, 2020:1), pendidik dalam pokok pembelajaran online mesti mengesahkan programa studi mengomeli masihlah melangkah sedangkan siswa berada di rumah. Jalan keluar ini menentukan guru pada dapat memolakan sarana pembelajaran sebagai suatu inovasi dengan memakai fasilitas online (online). Pembelajaran daring ini guna terhadap memakai teknologi multimedia, video, warga Maya, teks online animasi, titipanPengucapan, email, dan video steraming online, di mana agen didik dan tenaga pendidik mesti mampu menggapai IPTEK. Dengan pembelajaran daring guru penjas sulit untuk melakukan proses pembelajaran yang efektif dikarenakan mata pelajaran penjas itu lebih dominan dilaksanakan praktek yang dilakukan dilapangan. Karena adanya sistem pembelajaran daring ini mata pelajaran penjas dilaksanakan secara virtual. Sebelumnya yang semula belajar secara formal di sekolah maka digantikan dengan belajar mandiri di rumah dengan menggunakan fitur- fitur online atau menggunakan internet sebagai sarana penunjang utamanya. Keterbatasan pengetahuan akan penggunaan teknologi menjadi salah satu kendala dalam sistem pembelajaran daring. Kegiatan belajar akan maksimal jika ditunjang dengan menggunakan aplikasi atau media pembelajaran yang sesuai dan mudah digunakan untuk peserta didik. Selanjutnya kebijakan baru pembuatan kesibukan studi di rumah akan berdampak pada kondisi studi siswa di rumah. Konten pembelajaran online masih tetap dioptimalkan agar lebih interaktif, maka siswa dapat lebih berpartisipasi dalam daya upaya pembelajaran online. Mutu dukungan teknis juga perlu serta Dimaksimalkan, seperti halnya sarana yang dipakai oleh perseroan penyedia konten (Sri, 2020) Berdasarkan penjelasan di atas, bahwa perlu adanya penelitian mengenai analisi guru non penjas pada kinerja guru penjas dalam sistem pembelajaran daring saat pandemi di SMA N 2 Demak dan SMA N 1 Dempet.

Analisis dari non guru tersebut akan digunakan untuk mengetahui keefektifan dari sistem pembelajaran penjas secara daring dimasa pandemi. Dalam mengevaluasi kinerja guru, seorang guru yang unggul memiliki kemampuan sebagai berikut: (1) memahami ruang lingkup variabel yang dievaluasi, terutama kemampuan profesional guru, (2) memiliki standar dan mengembangkan alat evaluasi, (3) mengumpulkan danmenganalisis data, Dan (4) Membuat penilaian atau kesimpulan akhr. Berdasarkan latar belakang masalah di atas, peneliti tertarik untuk meneliti mengenai kinerja guru penjas dan pendapat guru non penjas pada kinerja guru penjas dalam sistem pembelajaran daring saat masa pandemi makapeneliti mengangkat judul "Analisis Guru Non PenjasPada Kinerja Guru Penjas Dalam Sistem Pembelajaran Daring 
Saat Masa Pandemi Di SMA N 2 Demak dan SMA N 1 Dempet"

\section{KAJIAN LITERATUR DAN PEGEMBANGAN HIPOTESIS}

Penelitian mengenai kinerja guru pernah diteliti oleh para peneleiti terdahulu antara lain Indra, dkk (2020) pernah meneliti yang berjudul "Persepsi Guru Penjas Terhadap Pembelajaran Daring di Tengah Pandemi Covid-19 Pada SMA Negeri Se- Kabupaten Jepara" Penelitian ini bertujuan untuk mengetahui persepsi guru pendidikan jasmani terhadap pembelajaran daring ditengah pandemic covid-19 pada SMA Negeri SeKabupaten Jepara.

Hasil penelitian ini disimpulkan bahwa persepsi guru Pendidikan Jasmani olahraga terhadap pembelajaran daring di tengah pandemic covid-19 pada SMA Negeri SeKabupaten Jepara masuk dalam kategori "tidak menunjang" Selanjutnya terdapat penelitian yang diteliti oleh Santoso, (2014) yang berjudul " Analisis Kinerja Guru Pendidikan Jasmani, Olahraga, Dan Kesehatan Bersertifikat Di SDN SeKecamatan Jogoroto Kabupaten Jombang Tahun 2014" Penelitian ini bertujuan untuk mengetahahui kinerja gurupendidikan jasmani dan kesehatan yang berstatus bersertifikasi dai data yang dikumpulkan. Hasil penelitian ini disimpulkan bahwa kinerja Guru Penjaskes bersertifikasi pada tahun 2014 memiliki nilai peningkatan dengan rata rata lebih baik dibandingkan dengan tahun 2013 dikarenakan beberapa aspek yang sudah terpenuhi oleh guru penjaskes yang bersertifikat seperti alat evaluasi pembelajaran dan sarana prasarana yang memenuhi prosedur, dan karena ada dukungan moril dari sekolah sendiri dalam mengimplementasikann kinerja pada guru penjaskes yang bersertifikasi.

Pendidikan jasmani olahraga merupakan satu mata ajar yang diberikan di suatu jenjang sekolah tertentu yang merupakan salah satu bagian dari pendidikan keseluruhan yang mengutamakan aktivitas jasmani (Kresnapati, 2018). Berdasarkan pemaparan Rosdiani, (2014:172) pendidikan jasmani pada hakikatnya merupakan proses pendidikan yang memanfaatkan aktivitas fisik untuk menghasilkan perubahan holistik dalam kualitas individu, baik dalamhal fisik, mental, serta emosional. Pendidikan Jasmani memperlakukan siswa sebagai sebuah kesatuan utuh, makhluk tetal, daripada mengaggapnya sebagai seorang yang terpisah kualitas fisik dan mentalnya.

Pendidikan jasmani merupakan salah satu bagian yang tidak dapat dipisahkan dari pendidikan secara keseluruhan untukmencapai tujuan pendidikan nasional (Mulyanto, 2014). Artinya, pendidikan jasmani bukan hanya dekorasi atau ornamen yang di tempel di dalam program sekolah sebagai media yang digunakan untuk membuat anak sibuk. Tetapi pendidikan jasmani merupakan bagian penting 
dari pendidikan. Melalui pendidikan jasmani yang diarahkan dengan baik, anak akan mengembangkan keterampian yang berguna untuk mengisi waktu senggang terlibat dalam aktivitas yang kondusif untuk mengembangkan hidup sehat mengembangkan diri secara sosial, dan menyumbang pada kesehatan fisik dan mentalnya.

Pembelajaran merupakan suatu kumpulan proses yang bersifat individual, yang mengubah stimuli dari lingkungan seseorang ke dalam sejumlah informasi, yang selanjutnya dalam dapat menyebabkan adanya hasil belajar dan bentuk ingatan jangka panjang. Menurut Undang-Undang No. 20 tahun 2003 menjelaskan bahwa pembelajaran adalah proses interaksi siswadengan pendidik dan sumber belajar pada suatu lingkungan belajar. Dimyati dalam Amalia (2019) mendefinisikan pembelajaran adalah sebagai berikut: "Pembelajaran adalah kegiatan guru secara terprogram dalam desain intruksional, untuk membuat siswa belajar secara aktif, yang menekankan pada penyediaan sumber belajar".

Menurut Hamalik (2007:27), belajar adalah modifikasi atau memperteguh kelakuan melalui pengalaman. (Nasution dalam Amalia 2017) belajar adalah suatu kegiatan yang membawa perubahan pada individu yang belajar. Perubahan itu tidak hanya mengenai jumlah pengetahuan, melainkan juga kecakapan, kebiasaan, sikap, pengertian, penghargaan, minat, penyesuaian diri, atau mengenai segala aspek pribadi seseorang. Belajar merupakan proses penting bagi perubahan perilaku manusia dan mencakup segala sesuatu yang dipikirkan dan dikerjakan. Bukti bahwa seseorang telah belajar ialah terjadinyaperubahan tingkah laku pada orang tersebut, misalnya 21 dari tidak tahu menjadi tahudan dari tidak mengerti menjadi mengerti.

Kementerian Pendidikan danKebudayaan (Kemendikbud) melalui Surat Edaran No. 4 Tahun 2020, menghimbau agar satuan Pendidikan menyelenggarakan pembelajaran dari rumah (Kemendikbud, 2020). Selain itu, melalui Surat Edaran No. 15 tahun 2020, Kemendikbud menegaskan bahwa pembelajaran dari rumah dilakukan dengan cara daring dan luring (Kementerian Pendidikan Dan Kebudayaan, 2020). Dengan demikian, maka seluruh Satuan Pendidikan dituntut untuk dapat melaksanakan pembelajaran sesuai dengan instruksi Menteri Pembelajaran daringmerupakan pembelajaran yang pelaksanaanya didukung oleh jasa teknologi seperti telepon, audio, videotape, transmisi satelit atau komputer Kusmana dalam Napsawati (2020). Penelitian yang dilakukan oleh Zhang et al., dalam Indra (2020) bahwa penggunaan internet dan teknologi multimedia mampu merombak cara penyampaian pengetahuan dan dapat menjadi alternatif pembelajaran yang dilaksanakan 
http://jurnal.unipasby.ac.id/index.php/stand/about/submissions jurnal.stand@unipasby.ac.id

dalam kelas tradisional. Pembelajaran daring adalah pembelajaran yang mampu mempertemukan mahasiswa dan dosen untuk melaksanakan interaksi pembelajaran dengan bantuan internet (Kuntarto dalam Basri, dkk 2020).

Proses pembelajaran di era digitalisasi pada saat ini tidak lepas dari teknologi informasi internet. Berbagai program aplikasi/portale learning ditawarkan, mulai dari berbayar hingga gratis. Salah satu contoh pembelajaran daring yaitu pembelajaran berbasis web. Yudhi \& Amalia (2018:14) menjelaskan.

Pemebelajaran berbasis web atau yang dikenal juga dengan "web based learning" merupakan salah satu jenis penerapan dari pembelajaran elektronik (e-learning). Salah satu platform yang dapat digunakan sebagai media pembelajaran interaktif ialah Schoology. World Health Organization (WHO) menetapkan tentang virus corona atau yang biasa disebut dengan covid-19 yang menjadi pandemi karena virus ini telah menyebar ke berbagai negara bahkan sudah mendunia. WHO mengartikan pandemi sebagai suatu kondisi populasi pada dunia dan berpotensi menjadikan jatuh dan sakit. Pandemi sendiriadalah wabah yang berjangkit secarabersamaan dmana-mana yang menyebar luas. Pandemi covid-19 ini juga berdampak dari berbagai sektor kehidupan seperti ekonomi, sosial dan juga pendidikan.
Organisasi Pendidikan, Keilmuan, dan Kebudayaan Perserikatan Bangsa-Bangsa atau United Educational, Scientific, and Cultural Organization (UNESCO) pada hari kamis 5 maret 2020 menyatakan bahwa wabah covid19 ini telah berdampak pada dunia pendidikan (Hendra Irawan, 2020).

\section{METODE PENELITIAN}

Penelitian ini dilaksanakan di SMA N 2 Demak dan SMA N 1 Dempet dengan waktu 1 minggu Rancangan sebuah penelitian memberi arti terhadap data tentang bagimana mengumpulkan, menyajikan dan menganalisa data, rancangan pada penelitian ini menerapkan Jenis penelitian deskriptif kuantitatif. Penelitian dilakukan merupakan suatu cara untuk menyelesaikan permaalahan. Terdapat beberapa jenis masalah pada pendidikan jasmani kesehatan dan olahraga. Untuk menyelesiakannya, digunakan beberapa jenis penelitian yang tepat. "Jenis penelitian yaitu pengkategorian penelitian sesuai dengan panduan dari segi mana penggolongan tersebut dilihat" (Kanca, 2010:5). Jenis penelitian pada penelitian ini yaitu penelitian deskriptif kuantitatif. Penelitian deskriptif kualitatif yaitu penelitian yang tujuannya mengetahui fenomena terkait apa yang dihadapi oleh subjek penelitian misal, motivasi, perilaku persepsi, tindakan dan lainnya, secara holistik dan dengan cara deskripsi berupa bahasa dan kata-kata, pada sebuah konteks khusus yang alamiah dan mempergunakan beberapa metode alamiah 
http://jurnal.unipasby.ac.id/index.php/stand/about/submissions

(Moleong, 2011: 6)Penelitian ini dilaksanakan di SMA N 2 Demak dan SMA N 1 Dempet. Pada dasarnyapenelitian ini tujuannya kinerja guru penjas pada proses pembelajaran daring pada masa pandemic di SMA N 2 Demak dan SMA N 1 Dempet Pemaparan Notoatmodjo (2010) , "instrumen penelitian yaitu instrumen yang akan dipergunakan dalam engumpulan data, instrumen ini bisa dalam bentuk angket, formulir pengamatan, formulir lainnya yang terkait dengan pencatatan data ataupun lainnya.

Berlandaskan kajian terhadap masalah yang ada dan kerangka berpikir pada sebuah penelitian maka dibuatlah instrumenpenelitian yang dipergunakan pada penelitian ini yakni menerapkan teknik angket

\section{HASIL DAN PEMBAHASAN}

Hasil analisis deskriptif data dilakukan untuk mengetahui dan mengakategorikan analisa guru non penjas dalam kinerja guru penjas pada proses pembelajaran daring saat masa pandemi di SMA N 2 Demak dan SMA N 1 Dempet Demak. Dari hasil perhitungan analisis data diperoleh data statistik deskriptif dari SMAN 1 Dempet Demak diketahui nilai mean atau rata-rata 15,92 , nilai modus 17 , nilai sum atau jumlah 414, skor maksimal 17, skor minimal 14 dan nilai simpangan baku (std.deviasi) 1,38 sedangkan data statistik deskriptif dari SMAN 2 Demak diperoleh nilai mean atau rata-rata 16,08 , nilai modus 17 , nilai sum atau jumlah 418 , skor maksimal
17, skor minimal 12 dan nilai simpangan baku (std.deviasi) 0,89. Data selanjutnya dibuat bentuk kategori atau kelompok menurut tingkatan yang ada, terdiri dari 4 kategori, yaitu: baik, sedang, rendah dan sangat rendah.

Berdasarkan hasil di atas menunjukkan bahwa analisa guru non penjas dalam kinerja guru penjas pada proses pembelajaran daring saat masa pandemi di SMA N 1 Dempet Demak berada pada kategori "baik" sebesar 92,3\% (24 guru), "sedang" sebesar 7,7\% (2 guru), "rendah" sebesar 0\% (0 guru) dan "sangat rendah" sebesar $0 \% \quad(0$ guru $)$ sedangkan di SMA N 2 Demak Demak berada pada kategori "baik" sebesar 100\% (26 guru), "sedang" sebesar $0 \% \quad(0$ guru $)$, "rendah" sebesar 0\% (0 guru) dan "sangat rendah" sebesar 0\% (0 guru). Berdasarkan nilai rata-rata analisa guru non penjas dalam kinerja guru penjas pada proses pembelajaran daring saat masa pandemi di SMA $\mathrm{N} 1$ Dempet Demaksebesar 92,3 \% dan SMA N 2 Demak sebesar $100 \%$ berada pada kategori baik dan efektif.

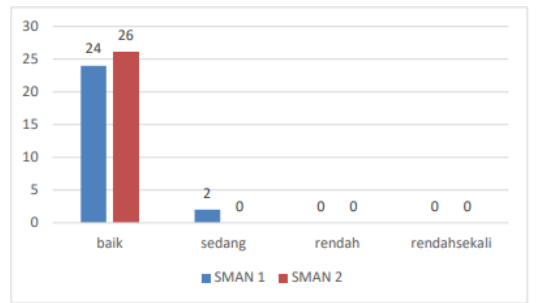

Gambar 1. Diagram Batang rata-rata

1. Kompetensi Kepribadian 
http://jurnal.unipasby.ac.id/index.php/stand/about/submissions jurnal.stand@unipasby.ac.id

Hasil penelitian pada komptenesi kepribadian dalam penelitian ini di ukur dengan 5 butir pertanyaan. Hasil analisis statistik data penelitian menunjukan tabel distribusi hasil penelitian pada kompetensi kepribadian dapat dikategorikan sebagai berikut : erdasarkan hasil di atasmenunjukkan bahwa analisa guru non penjas dalam kinerja guru penjas pada proses pembelajaran daring saat masa pandemi di SMAN 1 Dempet Demak pada kompetensi kepribadian yang berada pada kategori "baik" sebesar 81,8\% (21 guru), "sedang" sebesar 11,5\% (3 guru), "rendah" sebesar 7,7\% (2 guru) dan "sangat rendah" sebesar 0\% (0 guru) sedangkan di SMA N 2 Demak Demak berada pada kategori "baik" sebesar 81,8\% (21 guru), "sedang" sebesar 5\% (18,2 guru), "rendah" sebesar 0\% (0 guru) dan "sangat rendah" sebesar 0\% (0 guru) Berdasarkan nilai persenetase tertinggi pada kompetensi kepribadian di SMA N 1 Dempet Demak sebesar 81,8 \%dan SMA N 2 Demak sebesar $81,8 \%$ berada pada kategori baik dan efektif. Berdasarkan hasil analisa guru non penjas dalam kinerja guru penjas pada proses pembelajaran daring saat masa pandemi di SMA N 1 Dempet Demak pada kompetensi kepribadian yang berada pada kategori "baik" sebesar 81,8\% (21 guru), "sedang" sebesar 11,5\% (3 guru), "rendah" sebesar 7,7\% (2 guru) dan "sangat rendah" sebesar $0 \%$ (0 guru). Berdasarkan hasil analisa guru non penjas dalam kinerja guru penjas pada proses pembelajaran daring saat masa pandemi di SMA N 2 Demak pada kompetensi kepribadian yang berada pada kategori "baik" sebesar $81,8 \% \quad(21$ guru), "sedang" sebesar 5\% (18,2 guru), "rendah" sebesar 0\% (0 guru) dan "sangat rendah" sebesar 0\% (0 guru).

1. Kompetensi Pedagogik

Hasil penelitian pada komptenesi pedagogik dalam penelitian ini di ukur dengan 5 butir pertanyaan. Hasil analisis statistik data penelitian sebagai berikut : Berdasarkan hasil di atas menunjukkan bahwa analisa guru non penjas dalam kinerja guru penjas pada proses pembelajaran daring saat masa pandemi di SMA N 1 Dempet Demak pada kompetensi pedagogik yang berada pada kategori "baik" sebesar 73,1\% (19 guru), "sedang" sebesar 23,1\% (6 guru), "rendah" sebesar 3,8\% (1 guru) dan "sangat rendah" sebesar 0\% (0 guru) sedangkan di SMA N 2 Demak berada pada kategori "baik" sebesar 69,2\% (18 guru), "sedang" sebesar 30,8\% (8 guru), "rendah" sebesar $0 \%$ (0 guru) dan "sangat rendah" sebesar $0 \% \quad(0$ guru $)$ Berdasarkan nilai persenetase tertinggi pada kompetensi pedagogik di SMA N 1 Dempet Demak sebesar 73,1 \% dan SMA N 2 Demak sebesar $69,2 \%$ berada pada kategori baik dan efektif. Berdasarkan hasil analisa guru non penjas dalam kinerja guru penjas pada proses pembelajaran daring saat masa pandemi di SMA N 1 Dempet Demak pada kompetensi pedagogik yang berada pada kategori "baik" sebesar 73,1\% (19 guru), "sedang” sebesar 
http://jurnal.unipasby.ac.id/index.php/stand/about/submissions jurnal.stand@unipasby.ac.id

23,1\% (6 guru), "rendah" sebesar 3,8\% (1 guru) dan "sangat rendah" sebesar $0 \% \quad(0$ guru). Berdasarkan hasil analisa guru non penjas dalam kinerja guru penjas pada proses pembelajaran daring saat masa pandemi di SMA N 2 Demak pada kompetensi pedagogik yang berada pada kategori "baik" sebesar 69,2\% (18 guru), "sedang" sebesar 30,8\%

(8 guru), "rendah" sebesar 0\% (0 guru) dan "sangat rendah" sebesar 0\% (0 guru).

\section{Kompetensi Profesional}

Hasil penelitian pada komptenesiprofesional dalam penelitian ini diukur dengan 5 butir pertanyaan. Hasil analisis statistic data penelitian sebagai berikut: Berdasarkan hasil di atasmenunjukkan bahwa analisa gurunon penjas dalam kinerja guru penjas pada proses pembelajaran daring saat masa pandemi di SMAN 1 Dempet Demak pada kompetensi profesional yang berada pada kategori "baik" sebesar 57,7\% (15 guru), "sedang" sebesar 34,6\% (9 guru), "rendah" sebesar 7,7\% (2 guru) dan "sangat rendah" sebesar 0\% (0 guru) sedangkan di SMA N 2 Demak berada pada kategori "baik" sebesar 61,6\% (16 guru), "sedang” sebesar 34,6\% (9 guru), "rendah" sebesar 3,8\% (1 guru) dan"sangat rendah" sebesar $0 \%$ (0 guru). Berdasarkan nilai persenetase tertinggi pada kompetensi profesional di SMA N 1 Dempet Demaksebesar 57,7 \% dan SMA N 2 Demak sebesar $61,6 \%$ berada pada kategori baik dan efektif Berdasarkan hasil Analisa guru non penjas dalam kinerja guru penjas pada proses pembelajaran daring saat masa pandemi di SMA N 1 Dempet Demak pada kompetensi profesional yang berada pada kategori "baik" sebesar 57,7\% (15 guru), "sedang" sebesar $34,6 \%$ (9 guru), "rendah" sebesar 7,7\% (2 guru) dan "sangat rendah" sebesar $0 \%$ (0 guru) Berdasarkan hasil analisa guru non penjas dalam kinerja guru penjas pada proses pembelajaran daring saat masa pandemi di SMA N 2 Demak pada kompetensi profesional yang berada pada kategori "baik" sebesar 61,6\% (16 guru), "sedang" sebesar $34,6 \%$ (9 guru), "rendah" sebesar 3,8\% (1 guru) dan "sangat rendah" sebesar $0 \% \quad(0$ guru)

\section{Kompetensi Sosial}

Hasil penelitian pada komptenesi sosial dalam penelitian ini di ukur dengan 5 butir pertanyaan. Hasil analisis statistik Sumber : Hasil Analisis Penelitian (2021) Berdasarkan hasil di atas menunjukkan bahwa analisa guru non penjas dalam kinerja guru penjas pada proses pembelajaran daring saat masa pandemi di SMAN 1 Dempet Demak pada kompetensi sosial yang berada pada kategori "baik" sebesar 100\% (26 guru), "sedang" sebesar 0\% (0guru), "rendah" sebesar $0 \%$ (0 guru) dan "sangat rendah" sebesar $0 \% \quad(0$ guru) sedangkan di SMA N 2 Demak Demak berada pada kategori "baik" sebesar $100 \%$ (26 guru), "sedang" sebesar $0 \% \quad(0$ guru), "rendah" sebesar 0\% (0 guru) dan "sangat rendah" sebesar $0 \% \quad(0$ guru $)$. Berdasarkan nilai persenetase tertinggi pada 
kompetensi sosial di SMA N 1 Dempet Demaksebesar 100\% dan SMA N 2 Demak sebesar $100 \%$ berada pada kategori baik Berdasarkan hasil analisa guru non penjas dalam kinerja guru penjas pada proses pembelajaran daring saat masa pandemi di SMA N 1 Dempet Demak pada kompetensi sosial yang berada pada kategori "baik" sebesar 100\% (26 guru), "sedang" sebesar 0\% (0guru), "rendah" sebesar 0\% (0 guru) dan "sangat rendah" sebesar $0 \% \quad(0$ guru).Berdasarkan hasil analisa guru non penjas dalam kinerja guru penjas pada proses pembelajaran daring saat masa pandemi di SMAN 2 Demak pada kompetensi sosial yang berada pada kategori "baik" sebesar 100\% (26 guru), "sedang" sebesar 0\% (0guru), "rendah" sebesar $0 \%$ (0 guru) dan "sangat rendah" sebesar 0\% (0 guru).

\section{KESIMPULAN}

Berlandaskan hasil penelitian dan pembahasan yang didapat, maka kesimpulannya yaitu:

1. Kinerja guru penjas pada proses pembelajaran daring saat masa pandemi di SMA N 2 Demak dan SMA N 1 Dempet Demak dapat disimpulkan bahwa pada kategori "baik" sebesar 92,3\% (24 guru), “sedang” sebesar 7,7\% (2 guru), "rendah" sebesar 0\% (0 guru) dan "sangat rendah" sebesar 0\% (0 guru) sedangkan di SMA N 2 Demak berada pada kategori "baik" sebesar 100\% (26 guru), "sedang" sebesar 0\% (0 guru), "rendah" sebesar 0\% (0 guru) dan “sangat rendah" sebesar 0\% (0 guru).

2. Berdasarkan nilai rata-rata analisa guru non penjas dalam kinerja guru penjas pada proses pembelajaran daring saat masa pandemi di SMA N 1 Dempet Demak sebesar 92,3 \% dan SMA N 2 Demak sebesar $100 \%$ berada pada kategori baik.

\section{REFERENSI}

Bandy. (2011). Pembentukan Karakter Anak Melalui Aktivitas Bermain Dalam Pendidikan Jasmani.

Pendidikan Jasmani Indonesia, 8(1), 1-9. Retrieved from https://journal.uny.ac.id/index.php/jpji/arti cle/view/3477

Darmalaksana, W. (2020). WhatsApp Kuliah Mobile. Fakultas Ushuluddin UIN Sunan Gunung Djati Bandung.

Dimyati dan Mudjiono. (2006). Belajar dan Pembelajaran. Jakarta: PT Rineke Cipta.

Gikas, J., \& Grant, M. M. (. (2013). Mobile computing devices in higher education: Student perspectives on learning with cellphones, smartphones \& social media. Internet and Higher Education. https://doi.org/https://doi.org/10.1016/jjhe duc.2013.06.002

Harnani. (2020). In Efektivitas Pembelajaran Daring Pandemi Covid-19. Jakarta : Bdkjakarta.Kemenag.Go.Id.

Hamalik. (2007). Proses Belajar Mengajar. Jakarta: PT Bumi Aksara

Hanief \& Sugito. (2015). Membentuk Gerak Dasar Pada Siswa Sekolah Dasar Melalui Permainan Tradisional Yulingga. Jurnal Sportif, 1(1), 60-73.

Herlina \& Suherman M, (2020). Potensi Pembelajaran Pendidikan Jasmani Olahraga Dan Kesehatan (PJOK) Di 


\begin{tabular}{|c|c|}
\hline Uournal STAND: Sports and Development \\
unipa Sumabaya
\end{tabular} $\begin{gathered}\text { http://jurnal.unipasby.ac.id/index.php/stand/about/submissions } \\
\text { jurnal.stand@unipasby.ac.id }\end{gathered}$

Tengah Pandemi Corona Virus Disease (Covid-19) Di Sekolah Dasar.

Tadulako Journal Sport Sciences and

Education Vol.8 No.1 Januari-Juni 2020 ISSN 2581.

He, W., Xu, G., \& Kruck, S. (2014). Online IS Education for the 21st Century. Journal of Information Systems Education. 